そこで, 両炭素材の黒鉛化性をみるため, CK, MB をそれぞれ $1000,1400,1800,2200,2600^{\circ} \mathrm{C}$ に熱処 理してX線回折を行なってみた。得られた回折図形を 図 5，6に示したが，X線回折を行なった際, 比較的 低い温度で熱処理した試料については，スケールファ クター 4, $2200^{\circ} \mathrm{C}$ 以上に沶いて熱処理した試料につ いては, スケールファクター8あるいは 16 でX線回 折を行なっているので, 図 5, 6 に示した結果は, す ベてスケールファクター 4 亿作四し直して, 回折像の 相対的大きさをそろえたものである。

これらの回折像から, 格子定数と結晶子の大きさを 算出することができるが, 比較的低い温度で熱処理し た試料の回折像は, 相当大きく扗がっているため, ピ 一クの正確な位直の決定は困難である。そこで, これ

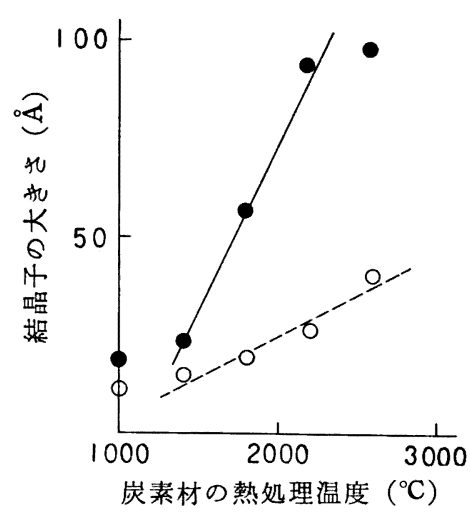

図 7 炭素材の熱処理温度と結晶子 の C軸方向の発達との関係

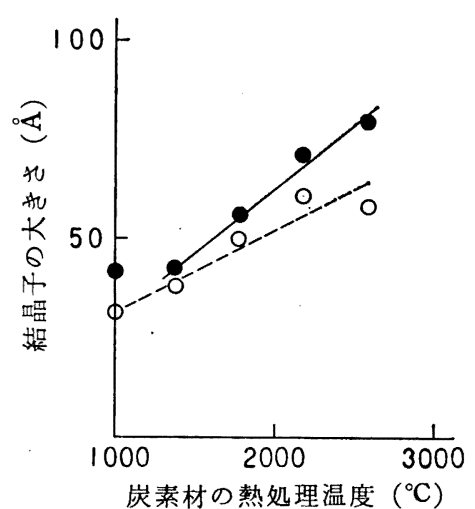

図8 炭素材の熱処理温度と結晶子 の $\mathrm{a}$ 軸方向の発達との関係

$-\bullet-: \mathrm{CK} \quad \cdots-\cdots: \mathrm{MB}$
らの回折像から, 結晶子の大きさのみを求め, これと炭素材の熱 処理温度との関係を示したのが図 7,8である。

この図 7,8 をみると, 市販カーバイド用コークスの CK と, 三井美唄目無し炭コークスの MB とでは，その黒鉛化性に特い

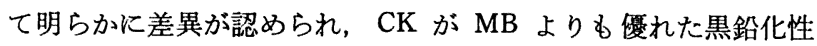
を示している。

両炭素材の黒鉛化性を示した, この図 7,8 の結果, 特よび図 1〜4で示したカルシウム・カーパイド生成反応についての 結果 からみて，黒鉛化性の良い $\mathrm{CK}$ が，カーハイド生成反応におけ る反応性に执いても，MB より優れていることが，明らかに認め られる。
既報 $1,2,3)$ に执いて著者らは，高温に拈いて構造が動き易く，黒 鉛化し易い炭素材が，カーパイド生成に打ける反応性が良いであ ろろ，といろ推測を行なっているが，本研究の結果は，この著者 らの推定とよく一致している。

結論として，カルシウム・カーバイド生成反応に特ける炭素材 の反応性と, その炭素材の高温に拈ける黒鉛化性との間には，何 らかの関連があると考えても，差支えないように思われる。

本研究に当り，御指導，御検討を睗わった，東京大学工学部 向坊隆教授，ならびに，東京工業大学 森川清教授，また， 協力して実験を行なった，当時の卒論学生 田村洋一，長南教孝 の両君に感謝いたします。

\title{
合成雲母結晶の二, 三の育成条件
}

(昭 和 38 年 11 月 15 日受理)

\author{
天野 隆 司・平尾 穂 -大間 信 利*
}

先に引下法に種結晶を使用することによって, ルッボの内容物全体をいわゆるブック状の結晶に育成することに成功し た。このようにしてブック状結晶を育成する場合の条件の中で, 最適の原料の化学組成, 引下速度と温度勾配, 扣よびル ッボの型については既に報告した。当報告は結晶の育成条件の中で, 原料溶融の最適温度および種結晶の $a, b, c$ 軸を 揃えた場合についてのものである。

底面 $5 \mathrm{~mm}$ 角, 高さ $65 \mathrm{~mm}$ の白金ルッポの下部に $a, h, c$ 軸を揃えたもの，または䢃開面のみを揃えたものを入れ， その上に雲母粉末を溶融して得た原料を充てんし，白金電気炬に挿入して，原料扰よび種結晶の一部を $1,380 ， 1,390$, $1,400,1,410^{\circ} \mathrm{C}$ の各温度で溶融し，ルッボを引下げて結晶を育成した。得たものの透過率を測定した結果，原料溶融の 温度は $1,400^{\circ} \mathrm{C}$ が最適であり，また種結晶の $a, b, c$ 軸を揃えたるのは，䢃開面のみを揃えたものより良好な結果を得 た。またナング率を測定し考察を加えた。

\section{1 緒言}

合成雲母結晶の製造に関する研究は既に多年にわたって行なわ れて来たが，いわゆるブック状の結晶は得られなかった。しかし， 最近にいたり種結晶を使用して縦型炉1)および横型炉2)を用いて ルツボの内容物全体をブック状結晶に育成しらるようになった。

* 信州大学工学部工業化学教室 : 長野市若里.

1) 大門, 伊藤, 平尾, 工化 64, 1530 (1961).

2) 大門, 大場, 平尾, 工化 65, 511 (1962).
本報告は種結晶を使用し, ルッボ降下法によりルッボの内容物全 体をブック状の結晶に育成する際の, 原料溶融の最適温度および $a, b, c$ 軸を揃えたものと䢃開面のみを揃えたものを種結晶に使 用した場合について，一応の結果を得たのでここに報告する。な おこの方法を用いた場合の最適の原料の化学組成 ${ }^{1)}$, 最適の温度 勾配と引下速度 ${ }^{3)}$, 拈よびルッボの型 ${ }^{4}$ については既に報告した。 結晶の良否は先報3で述べたように，光の透過率によった。また 3) 大門, 天野, 工化 65, 507 (1962).

4) 天野，平尾，大門，工化 67,232 (1964). 
二, 三の結晶についてヤング率を測定したので合せて報告する。

\section{2 実験}

結晶の育成は大門ら ${ }^{1)}$ が行なった方法によった。(001) 䢃開面 を揃えて重ねた種結晶を底面 $5 \mathrm{~mm}$ 角, 高さ $65 \mathrm{~mm}$ の白金ル シボに入れ，その上に原料を充てんして密封し，これをアランダ ム質の耐火物に入れ，耐火物とルッボとの間陌にアランダム粉を つめて保持電力 $500 \mathrm{~W}$ の縦型の白金電気炉の中に挿入した。炉 の炉心管内側の 最高温度になる位置に白金・白金ロジウム $13 \%$ 熱電対を挿入し，これを電子管式自動温度調節器に接続した。電 源電圧の变動を避けるために定格 $2 \mathrm{kVA}$ ，精度 $100.0 \pm 0.1 \mathrm{~V}$ の 自動定電圧装置を使用した結果, 温度の調節精度は原料溶融温度 で $\pm 1^{\circ} \mathrm{C}$ であった。炬の温度分布を予め測定しておき，種結晶 の上部より上が溶融するような位置にルッボを直いた。炬に通電 して温度を上昇させ, 所定の温度に達してから 2 時間同温度に保 持してから引下げを開始して結晶を育成した。この炉は約 1 時間 30 分で熱平衡儿達するからである。耐火物を水槽の浮子に連結 し，水槽の水をサイホンで流出させることにより，引下を行なっ た。原料の組成としてはフッ素金雲母 $\left[\mathrm{F}_{2} \mathrm{KMg}_{3}\left(\mathrm{AlSi}_{3} \mathrm{O}_{10}\right)\right] 100$ \% 組成のものが最もよかったので，フッ素金雲母粉末を原料に 用いた。

炬内の最高温度を同じ高さの溶融体の温度に等しいとして，炉 内最高温度 (原料溶融温度) を $1,380,1,390,1,400,1,410^{\circ} \mathrm{C}$ とし引下速度を $1.5,3.0,6.0,12,24 \mathrm{~mm} / \mathrm{hr}$ にとり，両者を 組合せた条件で, 結晶の育成を行なった。種結晶にはアメリカの Synthetic Mica Company で内熱法によって製造されたものの 中から，䢃開面に垂直な方向の光の透過率が $75 \%$ ，ヤング率が $1.2 \times 10^{6} \mathrm{~kg} / \mathrm{cm}^{2}$ 程度つものを選び出して， $a, b, c$ 軸を揃えた もの，および䢃開面のみを揃えたものを使用した。なお内熱法に よって得られたものの中には, 接触双晶があって, このもののヤ ング率は $0.7 \times 10^{6} \mathrm{~kg} / \mathrm{cm}^{2}$ であった。な打軸方向は打像法によ って決定した。

透過率の測定厄は先報 ${ }^{3)}$ の場合と同じように，白色光源，暗箱， 顕微鏡用光電管式露光計を組合せて使用した。露光計は光の透過 率を百分率表示で直珫し得るものである。

䢃開面に垂直方向の透過率を測定する場合には，ルッボ壁によ る育成結晶の表面の凹凸の影警を避けるために，育成結晶の表面 を䢃開面に沿って約 $1 \mathrm{~mm}$ はがしたものを試料に用いた。

これは先報4)にて報告したよ $5 に$, 表面から $1 \mathrm{~mm}$ 以内の所 には結晶に縞があったり，割れ目が存在することがあるからでも ある。一つの試料について，3 カ所で透過率および厚さを測定 し, Lambert の式 $I / I_{0}=\exp (-\alpha t)$ (式中 $I$ は直読透過率 \%, $I_{0}$ は入射光 : $100 \%, \alpha$ は吸光係数, $t$ は厚さ $\mathrm{mm}$ ) を用いて厚 さ $1 \mathrm{~mm}$ の值に換算し，換算透過率とした。いずれの試料にお いても, 三つの換算透過率の值は测定誤差の範囲内で一致してい た。

温度勾配の算出方法は前報2)の場合と同様に行なった。すなわ ち, 種結晶の溶融温度を $1,375^{\circ} \mathrm{C}^{5)}$ とし, 炉の温度分布を予め測 定してその分布曲線の $1,375^{\circ} \mathrm{C}$ を中として上下各 $5 \mathrm{~mm}$ の温 度差をもって温度勾配とした。温度勾配は $30^{\circ} \mathrm{C} / \mathrm{cm}$ であった。

5) 中, 野田, 工化 63，232(1960).
中央荷重によるたわみ法を用いて，ヤング率を測定した。すな わち, 水平に怙いた二支点の上に試片を置き, 中央に荷重をかけ てたわませ，試片のたわみを読取り顕徽鏡で測定し，試片の幅と 厚さをマイクロ・メーターで求めて, 次式によりヤング率を算出 した。

$$
E=P l^{3} / 4 b \delta h^{3}
$$

式中 $E$ はヤング率, $P$ は荷重, $l$ は支点間距離, $b$ は試

片の幅, $\delta$ は試片のたわみ, $h$ は試片の厚さである。

使用した装置は荷重が $16.8 \mathrm{~g}$, 支点間距離が $1.55 \mathrm{~cm}$ で, 幅 が約 $0.50 \mathrm{~cm}$, 厚さが $0.0080 \sim 0.00120 \mathrm{~cm}$ の陚片を用いて測定 した。

\section{3 実験結果および考察}

実験条件と透過率特よびヤング率の測定值を，それぞれ表 1 扰 よび表 2 に示した。表中平均換算透過率とは，実測の透過率を 1 $\mathrm{mm}$ の厚さに換算した二つの方（䢃開面に垂直な力向と平行な 方向）の換算透過率を算術平均した值である。

原料の溶融温度 $1,380^{\circ} \mathrm{C}$ で育成した結晶は，いずれる育成部分

表 1 実験条件と光の透過率との関係

\begin{tabular}{|c|c|c|c|c|c|c|c|c|c|c|}
\hline \multirow[b]{2}{*}{ 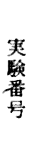 } & \multirow[b]{2}{*}{$\begin{array}{l}\text { 原料 } \\
\text { 溶 } \\
\text { 融量 } \\
\text { 度 } \\
\text { (C) }\end{array}$} & \multirow[b]{2}{*}{ 軸方向 } & \multirow[b]{2}{*}{$\begin{array}{c}\text { 引下速度 } \\
\left(\begin{array}{c}\mathrm{mm} \\
/ \mathrm{hr}\end{array}\right)\end{array}$} & \multicolumn{3}{|c|}{ 研開面に平行 } & \multicolumn{3}{|c|}{ 㖕閒面に垂淔 } & \multirow[b]{2}{*}{$\begin{array}{l}\text { 半均 } \\
\text { 換第 } \\
\text { 透沟 } \\
\text { 革 } \\
(\%)\end{array}$} \\
\hline & & & & 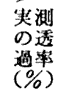 & $\begin{array}{c}\text { 然さ } \\
(\mathrm{mm})\end{array}$ & $\begin{array}{l}\text { 換算 } \\
\text { 莩通 } \\
\text { 率 } \\
(\%)\end{array}$ & $\begin{array}{l}\text { 実測 } \\
\text { 透 } \\
\text { 過革 } \\
(\%)\end{array}$ & $\begin{array}{c}\text { 笔さ } \\
(\mathrm{mm})\end{array}$ & $\begin{array}{l}\text { 換算 } \\
\text { 透通 } \\
\text { 率 } \\
(\%)\end{array}$ & \\
\hline 1 & 1,380 & 無占向 & 1.5 & 11.5 & 4.5 & 60 & 10.5 & 3.0 & 47 & $5_{4}$ \\
\hline 2 & "I & " & 3.0 & 7.6 & 4.3 & $5_{6}$ & 7. 9 & & $4_{3}$ & 50 \\
\hline 3 & " & " & 6.0 & 7.7 & 4.6 & $5_{7}$ & 7.2 & 2.8 & 39 & $4_{8}$ \\
\hline 4 & " & $"$ & 12 & 6.9 & 4.5 & $5_{5}$ & 6.0 & 2.8 & $3_{7}$ & $4_{8}$ \\
\hline 5 & "I & $"$ & 24 & 4.2 & 5.3 & $5_{5}$ & 3.0 & & $3_{3}$ & 44 \\
\hline 6 & 1,390 & $" 1$ & 1.5 & 21.0 & 5.3 & $7_{4}$ & 8.0 & 3.0 & $4_{3}$ & 5 \\
\hline 7 & " & $"$ & 3.0 & 12.5 & 4.2 & 61 & 13.5 & 3.0 & $5_{1}$ & 5 \\
\hline 8 & "I & $" 1$ & 6.0 & 11.0 & 4.9 & 64 & 8.1 & 3. & $4_{\theta}$ & $5_{5}$ \\
\hline 9 & "I & $" 1$ & 12 & 3.6 & 4.3 & 48 & 5.5 & 3. & 38 & $4_{2}$ \\
\hline 10 & " & $" \prime$ & 24 & 2.9 & 5.3 & $5_{1}$ & 3.6 & 3. & $3_{3}$ & $4_{2}$ \\
\hline 11 & 1,400 & $" 1$ & 1.5 & 33.5 & 4.9 & 80 & 19.5 & 3. & $6_{0}$ & 70 \\
\hline 12 & " & " & 3.0 & 20.5 & 4.8 & $7_{2}$ & 17.0 & 2. & $5_{3}$ & $6_{3}$ \\
\hline 13 & " & " & 6.0 & 16.0 & 4.5 & $6_{8}$ & 3.0 & 3. & $3_{7}$ & $5_{2}$ \\
\hline 14 & "I & " & 12 & 11.5 & 4.4 & $6_{0}$ & 3.6 & 2. & 28 & 44 \\
\hline 15 & "I & " & 24 & 3.8 & 4.5 & $4_{8}$ & 2.4 & 3. & $3_{3}$ & $4_{1}$ \\
\hline 16 & 1,410 & " & 1.5 & 19.5 & 5.4 & $7_{4}$ & 8.9 & 3. & $4_{7}$ & $6_{1}$ \\
\hline 17 & "I & " & 3.0 & 15.0 & 5.5 & $7_{1}$ & 7.3 & 3.2 & 4. & $5_{8}$ \\
\hline 18 & "I & " & 6.0 & 9.9 & 4.8 & $6_{2}$ & 4.2 & 3. & 3 o & 40 \\
\hline 19 & "I & "I & 12 & 3.7 & 5.3 & $5_{3}$ & 2.3 & 3.3 & $3_{2}$ & $4_{3}$ \\
\hline 20 & "I & "I & 24 & 5.7 & 5.5 & $5_{8}$ & 1.5 & 3.3 & 28 & $4_{3}$ \\
\hline 21 & 1,400 & $a$ 軸 & 1.5 & 42.0 & 5.0 & $8_{5}$ & 33.0 & 3.1 & 70 & 77 \\
\hline 22 & "I & "I & 3.0 & 33.0 & 5.3 & $8_{1}$ & 23.0 & 2.7 & $5_{8}$ & $7_{0}$ \\
\hline 23 & " & $"$ & 6.0 & 40.0 & 5.4 & $8_{1}$ & 6.7 & 3.3 & 40 & $6_{5}$ \\
\hline 24 & " & " & 12 & 30.0 & 5.1 & $7_{8}$ & 9.3 & 2.9 & 44 & $6_{1}$ \\
\hline 25 & " & "I & 24 & 16.0 & 5.2 & $6_{7}$ & 7.9 & 3.1 & 44 & $5_{\mathrm{B}}$ \\
\hline 26 & " & $b$ 軸 & 1.5 & 51.0 & 4.7 & 80 & 27.5 & 3.1 & $6_{0}$ & $7_{0}$ \\
\hline 27 & " & "I & 3.0 & 22.5 & 5.7 & 77 & 15.5 & 3.0 & 54 & $6_{5}$ \\
\hline 28 & " & " & 6.0 & 21.0 & 4.9 & $7_{2}$ & 15.0 & 3.1 & 5 & $6_{3}$ \\
\hline 29 & " & " & 12 & 24.0 & 4.8 & $7_{2}$ & 20.0 & 2.6 & $5_{2}$ & $6_{2}$ \\
\hline 30 & $1 "$ & " & 24 & 12.0 & 4. 6 & $6_{s}$ & 8.0 & 3.0 & $4_{3}$ & $5_{3}$ \\
\hline
\end{tabular}

表 2 実験条件とヤング率との関係

（）内は測定試片数 $\times 10^{8} \mathrm{~kg} / \mathrm{cm}^{2}$

\begin{tabular}{|c|c|c|c|c|}
\hline \multirow{2}{*}{$\begin{array}{c}\text { 溶融温度 } \\
\text { (C) }\end{array}$} & \multicolumn{2}{|c|}{ 引 } & \multicolumn{2}{|c|}{ 度 } \\
\hline & $\begin{array}{c}1.5 \\
(\mathrm{~mm} / \mathrm{hr})\end{array}$ & $\begin{array}{c}3.0 \\
(\mathrm{~mm} / \mathrm{hr})\end{array}$ & $\begin{array}{c}6.0 \\
(\mathrm{~mm} / \mathrm{hr})\end{array}$ & $\frac{12}{(\mathrm{~mm} / \mathrm{hr})}$ \\
\hline 1,390 & $0.9_{3}(4)$ & $0.4_{7}(6)$ & $0.3_{4}(6)$ & - \\
\hline 1,400 & 1.0 (8) & $0.7_{2}(7)$ & - & 0.4 4 (6) \\
\hline 1,410 & $1.2(7)$ & $0.8_{7}(5)$ & $0.6_{5}(6)$ & $0.5_{7}(5)$ \\
\hline $\begin{array}{l}\text { 内繁 } \\
\text { イン }\end{array}$ & 内薙法種絬晶 $1.2(100)$ & & アフリカ敦金需母 & $1.2(15)$ \\
\hline
\end{tabular}

* "Interim technical engineering report No. 5", Synthetic Mica Company (1958) 
はわずかであった。これはフッ素金雲母の溶融温度 $1,375^{\circ} \mathrm{C}$ と原 料の溶融温度との差がわずかであるために, 上部の原料が溶融し ても粘性が大きいために落下し難く, 種結晶上に連る溶融体の量 が少ないので, 育成部分は長くならなかったものと考えられる。 透過率の測定には差支えなく，育成した部分の長さは $10 \mathrm{~mm}$ 程 度であった。

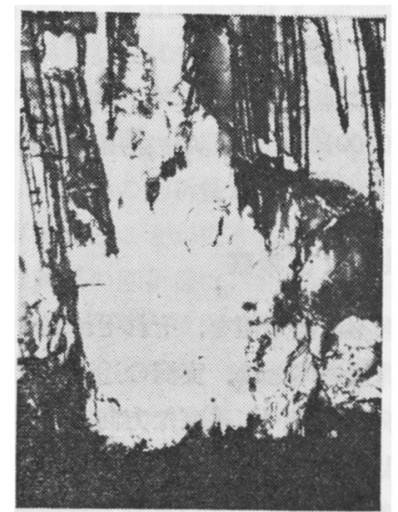

図 1 a 溶融位置付近 $(\times 60)$

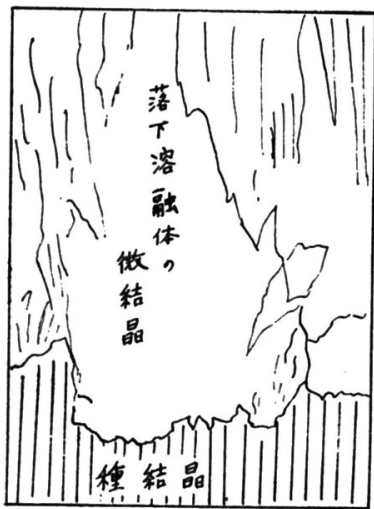

因 1 b (a の説明図)
種結晶の溶融した位置からやや下にかけて図 1 に示すよ5に, 種結晶の上や間によく光を反射する部分がある。これは微晶の集 まりであって，無配向に結晶しで扣り，すべての育成結晶につい て認められた。このことは溶融体が種結晶間の空隙や種結晶とル シボ壁との間の空隙を伝わって溶融位置より低い所に流れ出し, この位置の温度が低いために急冷されて無配向に微晶化したもの と考学られる。溶融位置付近では, これらの微晶がやや成長して いるのが見られるが，その少し上部ではこのよ5な微晶からの成 長はなく，種結晶を核として成長した結晶が観察された。図2 2 に この顕微鏡写真を示した。これは明らかに種結晶が $a, b$ 軸方向 へ成長すると同時に, $c$ 軸方向へも成長することを意味してい る。もし $c$ 軸方向へ結晶が成長するとすれば, 種結晶間の微晶か らも成長が見られるはずであるが，事実はそらでない。このこと については, 目下検討中であるので別に報告したい。

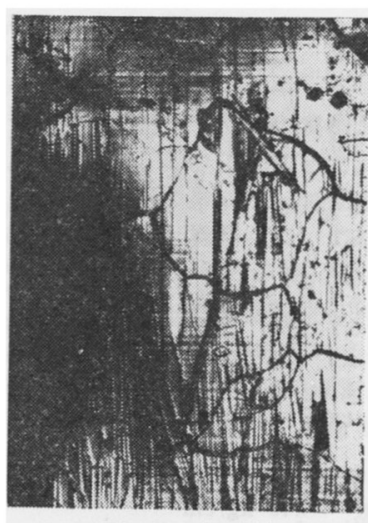

圀 $2(\times 60)$

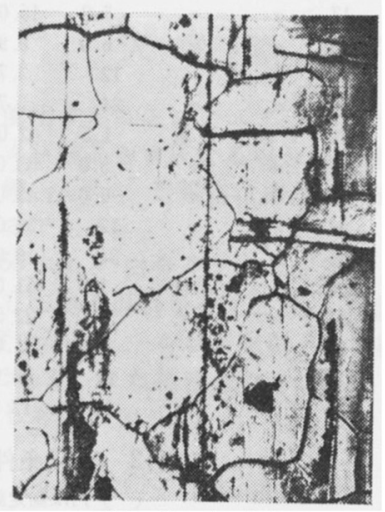

図 $3(\times 60)$
白金ルッボを破って取り出したブック状結晶の䢃開面の積み重 なった方の表面には見られなかったが, 䢃開面に直角な表面には， すべての結晶に図 3 に見られるような，たがいに連る線状の模様 が見られた。これは育成結晶の表面を，ごく薄い結晶がとりまい ていて，それが割れているものか，または結晶を育成後冷却する 際に生じた亀裂であるか不明である。育成結晶の溶融位置付近に は多数の気泡が見られ，また $c$ 軸方向から見ると，ルッボ壁に近
い部分にも多数の気泡が存在した。これは溶融時に発生した気体 や, 種結晶の間に存在した空気が閉じ込められて, 気泡となった ものであろう。気泡が存在しても結晶は乱れずに成長しているの が認められた。

\section{$3 \cdot 1$ 原料の溶融温度}

表 1 からわかるように, 引下速度が $1.5 \mathrm{~mm} / \mathrm{hr}$ の時は溶融温 度 $1,400^{\circ} \mathrm{C}$ の時の平均換算透過率が $70 \%$ で最良, $3.0 \mathrm{~mm} / \mathrm{hr}$ の時は $1,400^{\circ} \mathrm{C}$ で $63 \%, 6.0 \mathrm{~mm} / \mathrm{hr}$ の時は $1,390^{\circ} \mathrm{C}$ で $55 \%$ がそれぞれ最良であった。 $12,24 \mathrm{~mm} / \mathrm{hr}$ の時は各溶融温度によ る差はほとんどなく，約 45\% であり，結晶は昙っていた。すな わち原料の溶融温度 $1,380,1,390,1,400,1410^{\circ} \mathrm{C}$ の中で $1,400^{\circ} \mathrm{C}$ の場合が最良であった。

住吉, 野田6) は, フッ素金雲母溶融体の粘性を測定し, $\log \eta_{a^{-}}$ $1 / T$ 関係図から $1,410^{\circ} \mathrm{C}$ 付近に屈折点を有する 2 本の直線を得 た。この屈折は溶融体の構造変化に基づくものであろうと述べて いる。また, 中, 野田 ${ }^{7)}$ は, 溶融の初期では結晶化は容易である が，更に加熱処理をすると結晶化は次第に悪くなるが，更に引続 いて加熱処理を続けると結晶化し易くなる傾向があることを見出 して, 溶融体中の構造変化に基づくものであろうと述べている。 当報告では種結晶を使用して結晶の育成を行なっているため, 前 述の説がそのまま適用できるとは考えられないが，原料溶融温度 が $1,400^{\circ} \mathrm{C}$ が最適ということは, 溶融体の構造が $1,400^{\circ} \mathrm{C}$ 付近 で変化するためと思われる。

\section{$3 \cdot 2$ 種結晶の配向}

表 1 からわかるよ5に，種結晶の $a, b, c$ の各軸方向を揃兄 て, $a$ 軸方向（実験番号 No. 21 25）扣よび $b$ 軸方向（実験番 号 No. 26３0） へ結晶を育成させた場合，各引下速度について の育成結晶の透過率には軸方向による差異に諗められなかった。 これは $a, b$ 軸方向によって結晶構造にあまり差異がないためと 思われる。な掘折率が $\beta \fallingdotseq \gamma$ であるのは, $a, b$ 軸方向の結晶 構造がほぼ等しいためといわれている。

$a, b, c$ の各軸方向を揃えたものを種結晶に使用し引下速度が $12 \mathrm{~mm} / \mathrm{hr}$ (実験番号 No. 24，29）の場合の平均換算透過率は 62 \%であり, 䢃開面のみを揃え, 引下速度 $3.0 \mathrm{~mm} / \mathrm{hr}$ (実験番号 No. 12) の透過率は，63\% でほぼ同じであった。すなわち $a$, $b, c$ の各軸方向を揃えた方が䢃開面のみを揃えた場合よりも約 4 倍早い引下速度で結晶を育成しても同じ程度の透過率を持った ものが得られた。

フッ素金雲母の比重は 2.888) であり，種結晶のルッボ挿入時 の嵩比重は約 2.3 であるから, 種結晶間に全体の約 $1 / 6$ におよふ 間隙が存在することになる。この間吵にある溶融体が結晶化する 時に種結晶の軸方向が $a, b, c$ 共に揃っている方か，揃ってい ないものよりも配列し易くなるものと考光られる。つまり，透明 な結晶が得易いと考光られる。

\section{3 ヤング率}

ヤング率の計算例を表 3 に, 実験条件とヤング率との関係を表 2 に示す。な⿰七の方法によって, 天然雲母についても測定を行 い, その結果を表 2 に併記した。

原料の溶融温度 $1,380^{\circ} \mathrm{C}$ の条件で育成した結晶は, いずれも前

6) 住吉, 野田, 工化 65, 150 (1962).

7) 中, 野田, 工化 63, 946 (1960).

8) J.A.Kohn, R. A. Hatch, Am. Min. 40, 10 (1955). 
表 3 ヤング率の計算例

$E=P l^{3} / 4 b \delta h^{3}\left(\mathrm{~kg} / \mathrm{cm}^{2}\right), \quad P=16.8 \mathrm{~g}, \quad l=1.55 \mathrm{~cm}$

\begin{tabular}{|c|c|c|c|c|c|}
\hline 試 & 料 & $\begin{array}{l}\text { 幅 (b) } \\
\text { (cm) }\end{array}$ & $\begin{array}{l}\text { 昱さ (h) } \\
(\mathrm{cm})\end{array}$ & $\underset{(\mathrm{cm})}{\text { たかみ }_{(1)}}$ & 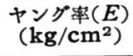 \\
\hline 1 (I & (o. 6) & 0.498 & 0.0100 & 0.030 & $1.1 \times 10^{0}$ \\
\hline 2 (1) & (o. 11) & 0.480 & 0.0115 & 0.016 & $1.3 \mathrm{\prime \prime}$ \\
\hline 3 (1 & o. 16) & 0.520 & 0.0080 & 0.060 & $1.0 \mathrm{\prime \prime}$ \\
\hline
\end{tabular}

に述べたように育成結晶の長さが $10 \mathrm{~mm}$ 程度で, 支点間距離に 達せず，測定できなかった。また各溶融温度において，引下速度 $24 \mathrm{~mm} / \mathrm{hr}$ のものは, 薄くはがすと, 短かい結晶の集合であった り，結晶が乱れていて均一の厚さの試料が得られず，測定できな かった。他の欠測值は育成結晶の長さが, 支点間距離に達しなか ったためである。

表 2 から明らかなように, 天然金雲母，天然白雲母，特よび引 下速度が $1.5 \mathrm{~mm} / \mathrm{hr}$ の条件で育成した結晶のヤング率はそれぞ れ $1.2,1.1 ， 1.2 \times 10^{6} \mathrm{~kg} / \mathrm{cm}^{2}$ であって差異はなかった。原料 の溶融温度が同一の場合には, ヤング率は引下速度の大きいほど 小であった。また前に述べたように，透過率の測定結果からは原 料の最適溶融温度は $1,400^{\circ} \mathrm{C}$ であることを知ったが，ヤング率の 測定結果からは最適溶融温度を 知ることはできなかった。これ はヤング率の測定の精度が悪い ためであると考えられる。

\section{$3 \cdot 4$ 透過率とヤング率}

育成結晶を樹脂で固め, $c$ 軸 方向に平行に, 寸なわら, 辟開 面に垂直にカナノコで切り，鉱 石研磨機で研磨してその断面を 検鏡すると,いくつかの䢃開面 が観察される。図 4 K，例を示 す。種結晶の溶融した位置から 約 $1 \mathrm{~cm}$ 上部の所で䢃開面の数 を読み, 育成結晶の幅を䢃開面

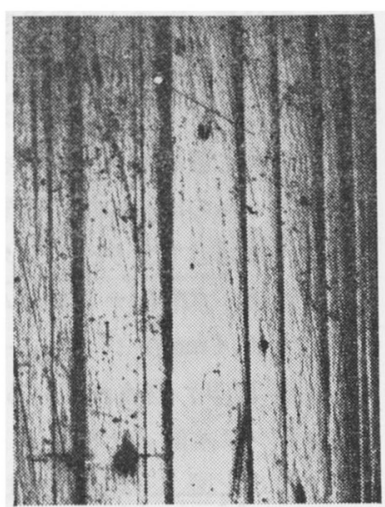

図 4 実験番号 No. 28 の断面 $(\times 60)$

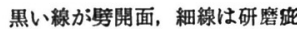
の数で除して最小単位の平均の厚さ（c 軸方向の長さ）を算出す ると表 4 のようになった。

表 4 からわかるように, ヤング率の小さいほど, 結晶の最小単 位の平均の厚さは小であった。この理由は, 結晶の厚さが薄く,
表 4 育成結晶の最小単位の平均の厚さ

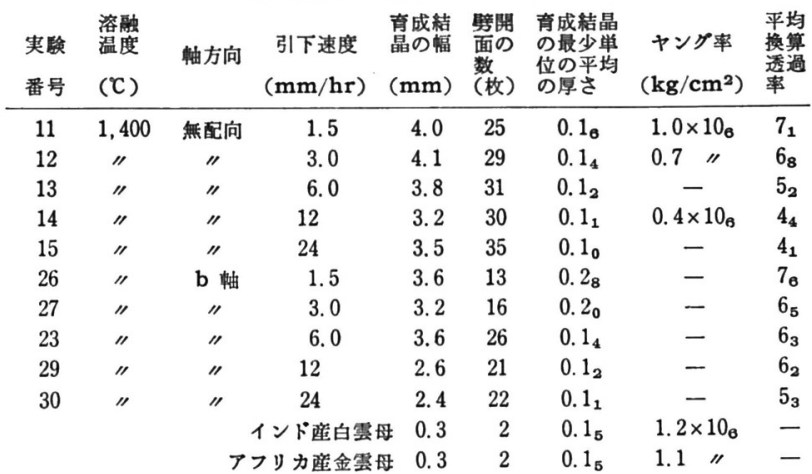

枚数の多い方がその境界面で滑り易くなり，また結晶の厚さが薄 いと同じ荷重であたわみ易く，この両者が影響してたわみ易くな り，従ってヤング率は小さくなるのではないかと考光られる。前 に述べたように，天然金雲母，天然白雲母，および引下速度 1.5 $\mathrm{mm} / \mathrm{hr}$ の条件で育成した結晶の間のヤング率の值に差異が認め られなかったのは, 最小単位の結晶の平均の厚さが $0.15 \mathrm{~mm}$ 程 度であって同じであるためと思われる。

また結晶の最小単位の平均の厚さが薄いほど平均換算透過率が 悪くなるのは結晶の厚さが薄く，枚数が多いほど境界面での反射 が多くなるためと考えられる。また前に述べたように結晶の最小 単位の平均の厚さが薄いものほど, ヤング率の值が小さくなって いる。従ってヤング率の值の大きいほど透過率の值は大きくなる のは, 上に述べた両者の関係によるものと考学られる。

以上により次の結果を得た。

試料の溶融温度を変化させて, 最適の原料溶融温度を光の透過 率によって求めると, $1,400^{\circ} \mathrm{C}$ の時が最良の結果を与えた。引下 速度については，遅い方がよい結果を与去た。種結晶の $a, b, c$ 軸を揃えた場合は，䢃開面のみを揃えた場合に比べて良結晶が得 られ，引下速度が約 4 倍の時に同じ程度の透過率を示した。

(昭和 38 年 3 月, 日本化学会第 16 年会講演, 昭和 38 年 11 月, 日本化学会人工鉱物討論会講演)

本研究に山たり, 実験に協力された寺島悦三氏, 水井裕二氏に 感謝の意を表する。経費の一部は文部省科学研究費によった。 